\begin{tabular}{|l|l|l||}
\hline \multicolumn{2}{|c|}{ PublisherInfo } \\
\hline \hline PublisherName & $:$ & BioMed Central \\
\hline \hline PublisherLocation & $:$ & London \\
\hline \hline PublisherImprintName & $:$ & BioMed Central \\
\hline \hline
\end{tabular}

\title{
Identifying the Black Plague
}

\begin{tabular}{|l|l|l||}
\hline \multicolumn{2}{|c|}{ ArticleInfo } \\
\hline \hline ArticleID & $:$ & 3825 \\
\hline \hline ArticleDOI & $:$ & $10.1186 /$ gb-spotlight-20001109-01 \\
\hline \hline ArticleCitationID & $:$ & spotlight-20001109-01 \\
\hline \hline ArticleSequenceNumber & $:$ & 262 \\
\hline \hline ArticleCategory & $:$ & Research news \\
\hline ArticleFirstPage & $:$ & 1 \\
\hline \hline ArticleLastPage & $:$ & 2 \\
\hline \hline & $:$ & RegistrationDate : 2000-11-09 \\
ArticleHistory & $:$ & OnlineDate \\
\hline \hline ArticleCopyright & $:$ & BioMed Central Ltd2000-11-09 \\
\hline \hline ArticleGrants & $:$ & \\
\hline \hline ArticleContext & $:$ & 130591111 \\
\hline \hline
\end{tabular}




\section{William Wells}

Email:wells@biotext.com

In just four years in the mid-fourteenth century, the medieval pandemic of 'Black Death' killed 17-28 million Europeans, or $30-40 \%$ of the total population. Further resurgences later in the century eliminated $90 \%$ of the households around Montpellier in southern France. It is in this region that Raoult et al. went searching for the causative agent of the Black Death. Although this agent has been presumed to be Yersinia pestis, the pattern of the disease's spread has led others to suggest alternative agents. In the November 7 Proceedings of the National Academy of Sciences, Raoult et al. use 'suicide' PCR to amplify DNA remnants of Yersinia pestis from tooth pulp, thus providing evidence that Yersinia was the agent of Black Death (Proc Natl Acad Sci USA 2000, 97:12800-12803). The teeth came from a grave that is dated to the time of the pandemic, and termed a 'catastrophe' grave because it contains multiple skeletons that lack shrouds. As such it is likely to have been used for Black Death victims. Dental pulp is a source of DNA free from natural contamination, and the absence of positive controls and use of new primers for each reaction lowers the chances of false positives. Attempts to amplify DNA from other infectious agents from the same samples were not successful.

\section{References}

1. Yersinia pestis - etiologic agent of plague.

2. The black death past and present. 2. Some historical problems.

3. Proceedings of the National Academy of Sciences, [http://www.pnas.org/]

4. Detection of 400-year-old Yersinia pestis DNA in human dental pulp: an approach to the diagnosis of ancient septicemia.

This PDF file was created after publication. 